\title{
ANTIGENIC RELATEDNESS AMONG NEWCASTLE DISEASE VIRUS ISOLATES FROM NIGERIAN FERAL BIRDS AND THE LA SOTA STRAIN
}

\section{Relação antigênica entre o vírus da doença de Newcastle isolado de aves selvagens da Nigéria e das amostras La Sota}

IBU, J.O. ${ }^{1}$; OKOYE, J.O.A. ${ }^{2}$; EZE, D. ${ }^{2}$; FASINA, F.O. ${ }^{1}$; ABA-ADULUGBA, E.P. ${ }^{1}$; ABECHI, A.S. ${ }^{1}$; WOMA, Y.T. ${ }^{1}$

${ }^{1}$ National Veterinary Research Institute
${ }^{2}$ University of Nigeria, Nsukka

Endereço para correspondência: Dr. FASINA, F. O., National Veterinary Research Institute, Vom, Nigeria. P.O.Box, 23, Vom, Plateau State - daydupe2003@yahoo.co.uk

\section{ABSTRACT}

The antigenic properties of thirteen isolates of Newcastle disease virus were assessed against La Sota strain. Using one of the previously recognized formulas significant antigenic differences were observed and marked inhibitory activities were noticed amongst the isolates and their hyper-immune sera as well as that of the La Sota strain. The implications of these differences for Newcastle disease epidemiology and control in Nigeria are discussed.

Key words: vaccine virus, wild virus, Newcastle disease, Nigeria.

\section{RESUMO}

As propriedades antigênicas de treze isolados do vírus da doença de Newcastle foram comparados com amostras La Sota. Usando uma das fórmulas previamente reconhecidas, significantes diferenças antigênicas foram observadas e marcantes atividades inibitórias foram percebidas entre os isolados e seus soros hiperimunes, bem como das amostras La Sota. As implicações destas diferenças para a epidemiologia e controle da Doença de Newcastle na Nigéria são discutidos.

Palavras-chave: vírus vacinal, vírus selvagem, doença de Newcastle, Nigéria.

\section{INTRODUCTION}

Newcastle disease virus (NDV) continues to pose a serious threat to the development of the poultry industry in Nigeria, other parts of Africa and Asia. The disease has economic and ecological impact on pet birds, free-living birds, as well as domestic birds.
Since the first detection and isolation of NDV in Nigeria in 1951 (Hill, et al., 1953), an average of $200-250$ outbreaks of the disease are reported in the country annually (Okeke and Lamorde, 1988). Several of these outbreaks frequently occur in vaccinated flocks and are often attributed to the existence of antigenic differences between the vaccine virus and wild virus 
strains (Nawathe, 1975; Ugochukwu, 1982; Adu, 1985).

Although the various strains of the NDV so far identified worldwide are antigenically related, minor antigenic differences still exist among strains. The antigenic variations found within strains are similar to those found among mutants within the same serotype (Adu, 1987).

These differences are expressed by the two surface glycoprotein antigens on the ND Virus - Haemagglutinin $(\mathrm{H})$ and Neuraminidase (N) (Gomez-Lillo et al., 1974).

La Sota strain of ND virus is one of the widely used live vaccines in Nigeria. This lentogenic vaccine is produced locally on commercial level at the National Veterinary Research Institute (NVRI, VOM) for routine immunization of commercial flocks.

In a recent survey, 13 NDV isolates were obtained from wild birds caught from Plateau, Benue and Kaduna States in central Nigeria. Using conventional and molecular techniques, there are differences in molecular aspects between the virus strains isolated (lbu et al., 2008, in press). The present study was carried out to determine serologic antigenic relatedness between these isolates and the La Sota vaccine strain using the Cross Haemaglutination Inhibition test. The possibility of the isolates sharing a common origin with the vaccine strain and its implication in relation to vaccine failures is discussed.

\section{MATERIAL AND METHODS}

\section{Production of Hyper-immune Serum}

The ND virus hyper-immune serum (HIS) for all the 13 isolates and the La Sota vaccine strain was raised in six weeks old susceptible chickens. Seventy-five (75) specific antibody negative chicks were obtained from the Poultry Division of the National Veterinary Research Institute, (NVRI, VOM), Nigeria and raised under a conditioned environment at the experimental unit of the Viral Research Division of the Institute.

The birds were pre-screened for NDV antibodies and divided into 15 experimental groups with 5 birds per group. Following the final screening, groups $1-13$ were inoculated with corresponding freshly harvested infective allantoic fluid of the virus isolate. Each bird received per-os (orally) $0.2 \mathrm{~mL}$ of $100 \mathrm{EID}_{50}$ per $\mathrm{mL}$ of virus concentration containing a minimum of 6 log virus titre. Group 14 was given $0.2 \mathrm{~mL}$ of NDV vaccine La Sota strain.

The virus inoculation procedure was repeated at weekly intervals for four weeks. Twenty one days after the last inoculation, blood were collected from the birds for serum and tested for the presence of ND virus antibodies. Chicks in group 15 were used as uninfected controls.

\section{Cross Haemggulation Inhibition (HI) Test}

A cross $\mathrm{HI}$ test (B-procedure) (Oie, 2004), was conducted on the fourteen HIS raised against each of the thirteen field virus strains and the NDV La Sota.

Briefly described, $25 \mu$ l of phosphate buffered saline (PBS) (P.H 7.2) was dispensed into each well of a 96-well, $V$ bottom plastic microtitre plate. Thereafter, $25 \mu$ l of the test serum was placed in the first column of the microtitre plate. A twofold serial dilution of the serum was made in PBS across the plate from 1:2-1:4096.

Serial dilutions of known positive and negative sera were used as controls. $25 \mu \mathrm{l}$ of four-haemagglutination unitage $(4 \mathrm{HA})$ of previously determined virus antigen was added to the HIS and the control wells and thoroughly mixed. A back titration of $4 \mathrm{HA}$ units of the antigen was made across the plate. The plate was then incubated at room temperature $\left(\approx 25-30^{\circ} \mathrm{C}\right)$ for 40 minutes. Afterward, $25 \mu$ l of freshly prepared $1 \% \mathrm{v} / \mathrm{v}$ of chicken red blood cells (RBC) was added to each well and mixed using a micro-plate shaker. All wells of the RBC control (only 
RBC and PBS) were allowed to settle to a distinct button.

Results were read for haemagglutination by tilting the plates and observation of a "tear-drop" streaming of the RBCs. A serum was considered positive if there was an inhibition (non-settling of $\mathrm{RBC}$ ) at a serum dilution of $4 \log _{2}$ or greater.

The extent of antigenic differences between two isolates was calculated from $\mathrm{HI}$ titre ratios using the formula of Archetic and Horsefall (1950) thus:

$$
\begin{aligned}
& \mathrm{R}=\sqrt{\mathrm{r1 \times r2}} \quad \begin{array}{l}
\text { Where } \mathrm{R}=\text { ratio of extent of } \\
\text { antigenic differences between two } \\
\text { clones/strains when both } \\
\text { clones/strains and their antisera } \\
\text { are used in reciprocal cross } \\
\text { serological reactions. }
\end{array} \\
& \mathrm{r} 1=\frac{\text { Heterologous titre (virus strain 2) }}{\text { Homologous titre (virus strain 1) }}
\end{aligned}
$$

\section{RESULTS}

From this study, a reaction between viral isolates/antigens and their immune sera was observed as shown by the reciprocal of the mean $\mathrm{HI}$ titres in Table 1. The titres ranged between, 2 and 4096 (table 1). The highest geometric mean titre (GMT) was 955 and the lowest, 196 (table 1).

A titre ratio as high as 32 was observed in a reaction between isolate $\mathrm{Pl}$ 016 antigen and $\mathrm{PI}-032$ antiserum while a titre ratio as low as 0.016 occurred between isolate $\mathrm{Bn} 7$ virus antigen and $\mathrm{Pl}-016$ hyperimmune serum (table 2). The maximum $\mathrm{R}$ value of 5.66 was observed in a cross reaction between isolate $\mathrm{JZ} 2$ virus antigen and $\mathrm{Pl}-032$ and $\mathrm{PI}-038$ hyper-immune sera (table 3). The lowest R-values of 0.13 was noticed between isolate $\mathrm{Bn} 2$, and Jz2 and PI-029 sera.

For the field isolates, 42 out of 78 (53.85\%) heterologous reactions gave $R$ values above 1 , while 28 (35.89\%) had $R$ - values below 1 . Only 8 cross reactions (10.26\%) had R-values equal to 1 .

Of the 13 cross reactions between the field virus isolates and the La Sota strain, 4 (30.77\%) had R-values above 1. Six cross reactions (46.15\%) gave R-values below 1 while $3(23.08 \%)$ cross reactions had R-values equal to 1 (table 3 ).

\section{DISCUSSION}

It is evident in this study that there is minor antigenic variability among the 13 field ND virus strains and the vaccine (La Sota) strain. A marked variation in the inhibitory capacity between the heterologous antigen and antisera is observed. For example, strains which show variability in terms of departure from the homologous $\mathrm{HI}$ titre $(\mathrm{R}>1$ or $r<1)$ accounted for $89.74 \%$ of the test result while strains which showed harmony $(R=1)$ accounted for only about $10 \%$. This high level of antigenic divergence could be of practical significance in relation to vaccination failures and the epidemiology of the disease in the localities. These findings are in agreement with those of other workers. Upton et al., (1953) and Bankosky et al., (1965) observed a significant diversity in antigenic components among the various strains of the ND Virus. Using different laboratory test, Gomez-Lillo et al., (1974); Schloer et al., (1975); and others identified antigenic differences between strains of ND viruses. Similarly, Alexander et al., (1999) using monoclonal antibodies, placed 102 ND virus isolates from 15 countries in 16 distinct groups. It is also suggested that antigenic divergence between clones of the same strain could be due to the variability in the function of external proteins (Adu, 1985). Similarly, the high level of reactivity between ND virus strains is also attributable to the presence of some mutants which react more broadly with heterologous virus (Bratt and Gallater, 1977). In the present study, all the strains had higher R-values with most of the 
heterologous viruses than the homologous isolates. This observation is also true of their reaction with the La Sota vaccine strain.

Generally, a range of R-values $\leq 0.5$ or $\geq 2$ is an indication that there is a significant antigenic difference between two strains (Baba et al., 1998). In this report, $48.71 \%$ of heterologous reactions fall within this range. This level of antigenic diversity cuts across a significant range of the isolates. It is an indication that these ND virus strains may not have had a common origin. In conclusion, it is not likely that the 13 virus isolates used in this study may have evolved from the existing La Sota vaccine strain.

Table 1 - Reciprocals of cross-haemagglutination inhibition titres of homologous and heterologous ND virus antigens and antisera.

\begin{tabular}{|c|c|c|c|c|c|c|c|c|c|c|c|c|c|c|}
\hline \multirow[t]{2}{*}{ Antiserum } & \multicolumn{14}{|c|}{ Antigen } \\
\hline & $\begin{array}{l}\text { Bn1 } \\
1\end{array}$ & $\begin{array}{l}\text { PI01 } \\
6\end{array}$ & $\begin{array}{l}\mathrm{PI03} \\
2\end{array}$ & Bn8 & $\begin{array}{l}\mathrm{PI03} \\
8\end{array}$ & Jz2 & Jz6 & $\begin{array}{l}\text { PI02 } \\
9\end{array}$ & $\mathrm{KD}_{4}$ & $\mathrm{Bn}^{2}$ & Jz13 & $\mathrm{Bn}^{7}$ & Jz4 & NDV \\
\hline Bn11 & 512 & 512 & 64 & 128 & 256 & 256 & 128 & 128 & 512 & 256 & 1024 & 64 & 128 & 2856 \\
\hline PI016 & 4096 & 2048 & 1024 & 512 & 4096 & 4096 & 2018 & 1024 & 4096 & 4096 & 4096 & 32 & 1124 & 1024 \\
\hline PI032 & 2048 & 4096 & 128 & 128 & 256 & 2058 & 1024 & 128 & 512 & 1024 & 1024 & 64 & 256 & 256 \\
\hline Bn8 & 2048 & 1024 & 512 & 128 & 256 & 1024 & 512 & 156 & 4096 & 64 & 2048 & 128 & 256 & 512 \\
\hline PI038 & 512 & 1024 & 256 & 64 & 128 & 2048 & 512 & 128 & 1024 & 2048 & 512 & 256 & 128 & 128 \\
\hline JZ2 & 1024 & 256 & 512 & 256 & 512 & 256 & 512 & 512 & 512 & 64 & 256 & 256 & 512 & 1024 \\
\hline Jz6 & 512 & 512 & 256 & 512 & 512 & 256 & 512 & 512 & 512 & 64 & 256 & 256 & $64^{*}$ & 256 \\
\hline PI029 & 512 & 256 & 256 & 1024 & 4096 & 512 & 1024 & 512 & 1024 & 128 & 1024 & 256 & $64^{*}$ & 512 \\
\hline $\mathrm{KD}_{4}$ & 128 & 256 & 128 & 64 & 256 & 128 & 256 & 128 & 512 & 256 & 256 & 512 & 128 & 256 \\
\hline $\mathrm{Bn}^{2}$ & 256 & 512 & 256 & 256 & 1024 & 256 & 1024 & 256 & 256 & 4096 & 512 & 512 & 512 & 512 \\
\hline Jz13 & 512 & 2048 & 2048 & 512 & 2048 & 1024 & 1024 & 1024 & 512 & 256 & 1024 & 512 & 1024 & 2048 \\
\hline Jz4 & 256 & 1024 & 256 & 128 & 256 & 512 & 512 & 512 & 4096 & 512 & 512 & 256 & 128 & 1024 \\
\hline $\mathrm{Bn}^{7}$ & 128 & 256 & 128 & 128 & 512 & 128 & 128 & 128 & 512 & 2048 & 512 & 128 & 128 & 128 \\
\hline Lasota & 512 & 256 & 1024 & 512 & 512 & 1024 & 128 & 512 & 256 & 256 & 256 & 512 & 256 & 512 \\
\hline $\begin{array}{l}\text { Range of } \\
\text { HI titres }{ }^{1}\end{array}$ & $\begin{array}{l}128- \\
4096\end{array}$ & $\begin{array}{l}256- \\
4096\end{array}$ & $\begin{array}{l}64- \\
2048\end{array}$ & $\begin{array}{l}64- \\
1024\end{array}$ & $\begin{array}{l}128- \\
4096\end{array}$ & $\begin{array}{l}128- \\
2048\end{array}$ & $\begin{array}{l}128- \\
2048\end{array}$ & $\begin{array}{l}512- \\
4096\end{array}$ & $\begin{array}{l}64- \\
2048\end{array}$ & $\begin{array}{l}256- \\
4096\end{array}$ & $\begin{array}{l}32- \\
512\end{array}$ & $\begin{array}{l}64- \\
1024\end{array}$ & $\begin{array}{l}512- \\
2048\end{array}$ & $\begin{array}{l}128- \\
2048\end{array}$ \\
\hline GMT & 588 & 724 & 294 & 208 & 588 & 630 & 588 & 294 & 955 & 478 & 776 & 169 & 239 & \\
\hline
\end{tabular}

${ }^{1}$ hyper-immune sera against field strains

Table 2 - Titre ratios derived from Cross HI titres.

\begin{tabular}{|c|c|c|c|c|c|c|c|c|c|c|c|c|c|c|}
\hline \multirow[t]{3}{*}{ Antiserum } & \multicolumn{14}{|c|}{ Antigen } \\
\hline & $\mathrm{Bn}$ & PI & $\mathbf{P I}$ & $\mathrm{Bn}$ & $\mathbf{P I}$ & Jz & Jz & PI02 & KD & Bn & $\mathbf{J z}$ & Jz & $\mathrm{Bn}$ & NDV \\
\hline & 11 & 016 & 032 & 8 & 038 & 2 & 6 & 9 & 4 & 2 & 13 & 4 & 7 & (L) \\
\hline Bn11 & 1 & 1 & 0.13 & 0.25 & 0.5 & 0.5 & 0.25 & 0.25 & 0.25 & 0.5 & 2 & 0.25 & 0.13 & 0.5 \\
\hline PI016 & 2 & 1 & 0.5 & 0.25 & 2 & 2 & 1 & 0.5 & 2 & 2 & 2 & 0.5 & 0.016 & 0.5 \\
\hline PI032 & 16 & 32 & 1 & 1 & 2 & 16 & 8 & 1 & 4 & 8 & 1 & 4 & 0.5 & 2 \\
\hline Bn8 & 16 & 8 & 4 & 1 & 2 & 8 & 4 & 2 & 32 & 0.5 & 16 & 2 & 1 & 4 \\
\hline PI038 & 4 & 8 & 2 & 0.5 & 1 & 16 & 4 & 1 & 8 & 16 & 4 & 1 & 2 & 1 \\
\hline Jz2 & 4 & 1 & 2 & 1 & 2 & 1 & 2 & 2 & 2 & 0.25 & 1 & 2 & 1 & 4 \\
\hline Jz6 & 1 & 1 & 0.5 & 1 & 1 & 0.5 & 1 & 1 & 1 & 0.13 & 0.5 & 0.13 & 0.5 & 0.5 \\
\hline PI029 & 1 & 0.5 & 0.5 & 2 & 8 & 1 & 6 & 1 & 2 & 0.25 & 2 & 0.13 & 0.5 & 1 \\
\hline KD4 & 0.25 & 0.5 & 0.25 & 0.13 & 0.5 & 0.25 & 0.5 & 0.25 & 1 & 0.5 & 0.5 & 0.25 & 1 & 0.5 \\
\hline Bn2 & 0.063 & 0.13 & 0.063 & 0.63 & 0.25 & 0.063 & 0.25 & 0.063 & 0.063 & 1 & 0.13 & 0.13 & 0.13 & 0.13 \\
\hline Jz13 & 0.5 & 2 & 2 & 0.5 & 2 & 2 & 1 & 1 & 0.5 & 0.25 & 1 & 1 & 0.5 & 2 \\
\hline Jz4 & 2 & 8 & 2 & 1 & 2 & 4 & 4 & 4 & 32 & 4 & 4 & 1 & 2 & 8 \\
\hline Bn7 & 1 & 2 & 1 & 1 & 4 & 1 & 1 & 1 & 4 & 16 & 4 & 1 & 1 & 1 \\
\hline NDV(L) & 1 & 0.5 & 2 & 1 & 1 & 2 & 0.25 & 1 & 0.5 & 0.5 & 0.5 & 0.5 & 1 & 1 \\
\hline
\end{tabular}


Table 3 - R-values calculated from titre ratios according to the formular of Archetti and Horsfall (1950).

\begin{tabular}{|c|c|c|c|c|c|c|c|c|c|c|c|c|c|c|}
\hline $\begin{array}{l}\text { Isolate / } \\
\text { Antiserum }\end{array}$ & $\begin{array}{l}\mathrm{Bn} \\
11\end{array}$ & $\begin{array}{c}P I \\
016 \\
\end{array}$ & $\begin{array}{c}\mathrm{PI} \\
032 \\
\end{array}$ & $\begin{array}{c}\text { Bn } \\
8\end{array}$ & $\begin{array}{c}\mathrm{PI} \\
038\end{array}$ & $\begin{array}{c}\mathrm{Jz} \\
2\end{array}$ & $\begin{array}{l}J z \\
6 \\
\end{array}$ & $\begin{array}{l}\mathrm{PIO} \\
29 \\
\end{array}$ & $\begin{array}{c}\text { KD } \\
4 \\
\end{array}$ & $\begin{array}{c}\text { Bn } \\
2\end{array}$ & $\begin{array}{l}\mathrm{JZ} \\
13\end{array}$ & $\begin{array}{c}\mathrm{Bn} \\
7 \\
\end{array}$ & $\begin{array}{c}\mathrm{Jz} \\
4 \\
\end{array}$ & $\begin{array}{l}\text { NDV } \\
\text { (L) }\end{array}$ \\
\hline Bn11 & 1 & 1.41 & 1.44 & 2 & 1.41 & 1.41 & 0.5 & 0.5 & 0.25 & 0.18 & 1 & 0.36 & 0.71 & 0.71 \\
\hline PI016 & & 1 & 4 & 1.41 & 4 & 1.41 & 1 & 0.5 & 1 & 0.51 & 2 & 0.18 & 2 & 0.5 \\
\hline PI032 & & & 1 & 2 & 2 & 5.66 & 2 & 0.71 & 1 & 0.71 & 1.41 & 0.71 & 2.83 & 2 \\
\hline Bn8 & & & & 1 & 1 & 2.83 & 2 & 2 & 2.04 & 0.18 & 2.83 & 1 & 1.41 & 2 \\
\hline PI038 & & & & & 1 & 5.66 & 2 & 2.83 & 2 & 2 & 2.83 & 2.83 & 1.41 & 1 \\
\hline Jz2 & & & & & & 1 & 1 & 1.41 & 0.71 & 0.13 & 1.41 & 1 & 2.83 & 2.83 \\
\hline Jz6 & & & & & & & 1 & 1.41 & 0.71 & 0.18 & 0.71 & 0.71 & 0.72 & 0.35 \\
\hline PI029 & & & & & & & & 1 & 0.71 & 0.13 & 1.41 & 0.71 & 0.72 & 1 \\
\hline KD4 & & & & & & & & & 1 & 0.18 & 0.5 & 2 & 3.83 & 0.5 \\
\hline $\mathrm{Bn} 2$ & & & & & & & & & & 1 & 0.5 & 1.44 & 0.72 & 0.25 \\
\hline Jz13 & & & & & & & & & & & 1 & 1.41 & 2 & 0.32 \\
\hline $\mathrm{Bn} 7$ & & & & & & & & & & & & 1 & 1.41 & 1 \\
\hline Jz4 & & & & & & & & & & & & & 1 & 2 \\
\hline NDV(L) & & & & & & & & & & & & & & 1 \\
\hline
\end{tabular}

\section{Acknowledgement}

The authors thank Mrs. Josephine Kaigama for her laboratory assistance, Dr. H. M. Kazeem for his input and the Executive Director, National Veterinary Research Institute, Vom, Nigeria for permission to publish the manuscript.

\section{REFERENCES}

ADU, F.D. Characteristics of Nigerian strains of Newcastle disease virus. Avian Diseases. v.29, p.849-851, 1985.

ADU, F.D. Characterization of Nigerian strains of Newcastle disease virus. PhD thesis, Dept. of Virology, College of Medicine, University of Ibadan, Nigeria; 1987.

ALEXANDER, D. J., BANKS, J., COLLINS, M. S., MANVELL, R. J., FROST, K. M., SPEIDEL, E.C., ALDOUS, E.W. Antigenic and genetic of Newcastle disease viruses isolated from outbreaks in domestic fowls and turkeys in Great Britain during 1997. Veterinary Record. v.145, p.417-421, 1999.

ARCHETTI, I., HORSFALL, F. L. Persistent antigenic variation in Influenza $A$ viruses after incomplete neutralization in ovo with heterologous immune serum. Journal of Experimental Medicine. v.92, p.441-462, 1950.

BABA, S. S., FAGBAMI, A. H., OLALEYE, O. D. Antigenic relatedness of selected flaviviruses: Study with homologous and heterologous immune mouse ascitic fluids. Revista do Instituto de Medicina Tropical de São Paulo. v.40, 343-349, 1998.

BANKOSKY, R.A., KINJO, J. Tissue culture system with Newcastle disease virus and relationship of antigenecity with immumogenecity among strains. Avian Diseases. v.9, p.152-170, 1965.

BRATT, M. A., GALLAHER, W. R. Biological parameters of fusion from within and fusion from without. In: Membrane Research. Academic press. Publishers. New York, pp 383-406; 1977.

GOMEZ-LILLO, M., BANKOSKY, R.A., WIGGINS, A.D. Antigenic relationship among viscerotropic and domestic strains of Newcastle disease virus. American Journal of Veterinary Research. v.35, p.471-475, 1974.

HILL, H.D., DAVIS, O.S., WILDE, J.E. Newcastle disease in Nigeria. British Veterinary Journal. v.109, p.381-385, 1953.

IBU, O. J., OKOYE, J.O.A., ABA-ADULUGBA, E. P., CHAH, K. F., SHOYINKA, S.V. O., SALIHU, E., CHUKWUEDO, A.A., BABA, S. S. Prevalence of Newcastle Disease viruses in wild and captive birds in central Nigeria. International Journal of Poultry Science. (in press). 2008.

NAWATHE, D.R., MAJIYAGBE, K.A., AYOOLA, S.O. (1975). Characterization of Newcastle disease virus isolates from Nigeria. Bulletin Office International des Epizooties. v.83, p.1097-1105, 1975.

OKEKE, E. N., LAMORDE, A. G. Newcastle disease and its control in Nigeria. In: Viral Diseases of Animals in Africa. (Eds. Olufemi Williams, A., and W. N. Masiga). CTA/OAU/STRC Publications Lagos, Nigeria, 1988. p. 283-287.

SCHLOER, G., SPALATIN, J. AND HANSON, R. P. (1975). Newcastle disease viruses and strain variations. American Journal of Veterinary Research. v.36, p.505-508, 1975.

UGOCHUKWU, E. I. Post vaccination Newcastle disease outbreak. Nigerian Veterinary Journal. v.11, p.24-28, 1982. 
UPTON, E., HANSON, R.P., BRANDLY, C.A. (1953). Antigenic differences among strains of Newcastle disease virus. Proceedings of the Society of Experimental Biology and Medicine. v.84, p.691-693, 1953.

WORLD ORGANISATION FOR ANIMAL HEALTH (2004). Newcastle disease. In: Manual of Diagnostic Tests and Vaccines for Terrestrial Animals. Web edition. Available at http://www.oie.int/eng/normes/mmanual/A 00038.ht m. Accessed on 26th April, 2008. 